\title{
Inmersión y estereoscopia por la Barranquilla de comienzos del siglo $x x^{*}$
}

IMMERSION AND STEREOSCOPY IN BARRANQUILLA AT THE BEGINNING OF THE 2OTH CENTURY

IMERSÃO E ESTEREOSCOPIA EM BARRANQUILLA NO INÍCIO DO SÉCULO XX

\section{Angélica Piedrahita**}

Cuadernos de Música, Artes Visuales y Artes Escénicas

/Volumen 13- Número 2 / Julio - Diciembre de 2018

/ ISSN 1794-6670/ Bogotá, D.C., Colombia / pp. 27-45

Fecha de recepción: 12 de enero de 2017

Fecha de aceptación: 1 de abril de 2018

Disponible en línea: 6 de julio de 2018

doi 10.11144/javeriana.mavae13-2.iyep

* Artículo de reflexión. Producto del proyecto de investigación-creación titulado Estéreo nostalgias y telepaseos por un lugar en el Caribe, auspiciado por la Vicerrectoría de Investigación de la Pontificia Universidad Javeriana de Bogotá.

* $\quad$ Artista, docente e investigadora. Maestra en Artes Visuales por la Pontificia Universidad Javeriana de Bogotá y Master of Fine Arts en Media Arts Production por la University at Buffalo, SUNY, producto de la Beca Fulbright-Colciencias 2010. Profesora titular de la Universidad de Monterrey. ORCID:0000-0002-5489-1107 


\section{Resumen}

Los tours estereoscópicos fueron dispositivos precinematográficos que desde la inmersión y la fotografía diseñaron la posibilidad de viajar a distancia a partir de simulaciones ópticas. Antecediendo a los actuales recorridos virtuales, estos tours intentaron categorizar el mundo desde una mirada marcadamente colonial simplificando y generalizando la visita a otros países. El artículo presenta una reflexión a la mirada y el acto de observar tomando como objeto de análisis un tour estereoscópico realizado por la compañía norteamericana Underwood \& Underwood en Barranquilla a comienzos del siglo XX. En primer lugar, el trabajo busca desplegar las especificidades de la experiencia del ojo en estos espacios estereoscópicos y la manera en la que desde el movimiento ocular se produce la sensación de profundidad, con el fin de señalar el aporte de este dispositivo a las experiencias visuales. En segundo lugar, se narra la experiencia de explorar los espacios fotografiados e interactuar con los actuales habitantes a quienes se les presentan las imágenes de archivo. Al presentar el dispositivo a los barranquilleros de la zona, se propician memorias sobre el desarrollo urbano de la ciudad y la preocupación sobre su patrimonio. Además, se detectan anhelos de desarrollo económico a partir del turismo, visibilizando la correspondencia del producto con prácticas contemporáneas de memoria visual desde la explotación turística. A lo largo del artículo, se revisa el concepto de inmersión vinculado a la técnica y el turismo, en busca de conceptos que contesten a corrientes mercantiles y tecnócratas del resurgimiento de la estereoscopia en la realidad virtual y aumentada.

Palabras clave: estereoscopia; turismo; inmersión; Barranquilla; visualidad; memoria.

\section{Abstract}

Stereoscopic tours were pre-cinematographic devices that from immersion and photography designed the possibility of traveling from optical simulations. Preceding the current virtual tours, these tours tried to categorize the world from a markedly colonial perspective, simplifying and generalizing the visit to other countries. The article presents a reflection on the look and act of observing taking as an object of analysis a stereoscopic tour made by the American company Underwood \& Underwood in Barranquilla at the beginning of the 20th century. First, the work seeks to display the specificities of the eye experience in these stereoscopic spaces and the way in which the sensation of depth is produced from the eye's movement, in order to point out the contribution of this device to visual experiences. Second, the paper narrates the experience of exploring the photographed spaces and interacting with the current inhabitants to whom the archive images are presented. When presenting the device to the people from the Barranquilla area, memories are promoted about the urban development of the city and concern about its heritage. In addition, aspirations of economic development from tourism are detected, making visible the correspondence of the product with contemporary practices of visual memory based on the exploitation of tourism. Throughout the article, the concept of immersion linked to technique and tourism is reviewed, in search of concepts that respond to mercantile and technocratic currents of the revival of stereoscopy in virtual and augmented reality.

Keywords: stereoscopy; tourism; immersion;

Barranquilla; visuality; memory.

\section{Resumo}

Os tours estereoscópicos foram dispositivos precinematográficos que, desde a imersão e fotografia, projetaram a possibilidade de viajar a distância a partir de simulações ópticas. Precedendo os atuais tours virtuais, esses tours tentaram categorizar o mundo de uma perspectiva marcadamente colonial, simplificando e generalizando a visita a outros países. El artículo apresenta uma reflexão sobre o olhar e o ato de obser var, tomando como objeto de análise um tour estereoscópico feito pela empresa norte-americana Underwood \& Underwood em Barranquilla no início do século XX. Inicialmente, o trabalho procura mostrar as especificidades da experiência do olho nesses espaços estereoscópicos e a maneira pela qual, a partir do movimento dos olhos, se produz a sensação de profundidade, a fim de mostrar a contribuição deste dispositivo para as experiências visuais. Em segundo lugar, narra-se a experiência de explorar os espaços fotografados e interagir com os habitantes atuais a quem as imagens do arquivo são apresentadas. Após apresentar o dispositivo ao povo de Barranquilla na área, são promovidas memórias sobre o desenvolvimento urbano da cidade e preocupação com o patrimônio. Além disso, são detectados os desejos de desenvolvimento econômico a partir do turismo, tornando visível a correspondência do produto com práticas contemporâneas de memória visual a partir da ex ploração turística. Ao longo do artigo, revisamos o conceito de imersão ligado à técnica e ao turismo, em busca de conceitos que respondam às correntes mercantis e tecnocráticas do ressurgimento da estereoscopia em realidade virtual e aumentada.

Palavras-chave: estereoscopia; turismo; imersão;

Barranquilla; visualidade; memória. 
Como legado de los primeros ejercicios cinematográficos populares, la inmersión produce la sensación de estar envuelto en un espacio de la representación, productor de estímulos y experiencias interesante a la actualmente teoría de medios. Como espectadores en experiencias inmersivas, accedemos conscientemente a recorrer estos espacios construidos, donde el observador y lo observado parecen ocupar el mismo espacio-tiempo. Con la reaparición de tecnologías que hacen uso de la estereoscopia en el mercado mundial actual como Oculus Rift o Google Cardboard, es relevante desde las artes visuales considerar momentos del dispositivo en los que se repiten modelos. De ahí que el presente trabajo se enfoque en revisar material estereoscópico del pasado concerniente a Colombia, que quizá no es relevante en el desarrollo de hardware o el diseño de redes telemáticas, pero sí es significante para repensar la mirada frente a la estereoscopia y lo que esta propone frente a los vertiginosos límites entre el ojo y la imagen.

Tanto la realidad virtual —en los videojuegos — como la realidad aumentada —en el piloteo de un dron - transforman la percepción del espacio y el tiempo sumando cartografías a nuestro mapa sensitivo. A partir de cascos de realidad virtual provistos de lentes, se acerca la imagen capturada por una o varias cámaras a los ojos. Estas experiencias visuales siguen un arquetipo de representación característico del plano subjetivo en el lenguaje cinematográfico, donde la cámara toma la posición del cuerpo ausente en escena. En los cascos de realidad aumentada y virtual, al abarcar el campo de visión, los ojos se encuentran atrapados por la imagen. Siguiendo los fundamentos de la visión binocular, frente a cada globo ocular se interpone un lente que acerca las imágenes otorgando una sensación de profundidad que modifica distancias y referencias espaciales. La estereoscopia considera la distancia interocular para producir un conglomerado de superficies cercanas y distantes que no corresponden a una representación proporcional del espacio. Observar por medio de este aparato parece transformar la demarcación entre espectador y espectáculo, proponiendo al ojo un espacio cercano y sin bordes, en el cual la profundidad de campo alinea puntos donde ambos ojos convergen. En el espacio producto de la convergencia óptica, un par de ojos aparentemente libres recorren espacios deteniéndose, revisitando u obviando secciones de la imagen.

La inmersión en la estereoscopia implica considerar relaciones entre los ojos, la cámara, la mirada y la imagen. Estas relaciones se enmarcan en contextos culturales, estructuras de poder, formas de producción y expansión de las imágenes, además de la dimensión subjetiva de aquello tras la cámara y frente a esta. En suma, la técnica trasciende la identificación primordial e inevitable del ojo del espectador y el lente de la cámara. ${ }^{1}$

Desde la segunda mitad del siglo XIX, la estereofotografía fue por décadas un medio popular de representación del mundo moderno. Por medio de este tipo de fotografías, circularon imágenes de territorios colonizados que respondieron a un frenesí por lo visible y a una expansión visual de la geografía con los diarios de viaje. Para la época, pareciese como si el mundo entero se tornara visible y al mismo tiempo apropiable (Comolli 1980, 123). La pornografía, el turismo, la reportería gráfica de guerra y la educación escolar fueron algunos de los muchos terrenos en los que se produjeron imágenes estereoscópicas con el interés de confluir visión y cognición. Sobre estas el ojo adquiría una cierta experiencia espacial, donde el yo he visto aparecía equivalente al yo conozco. La exploración a partir de puntos de convergencia de los pares de imágenes permite enlazar momentos de la imagen con aparente libertad, desplegar complejas genealogías de la representación y traer particularidades de la subjetividad de quien observa. 
El estereoscopio confiere al ojo la sensación espacial de un lugar u objeto que no se encuentra presente, en consecuencia, las estereofotografías desde su aparición eran comercializadas como sustituyentes de la experiencia misma. "El efecto que perseguía el estereoscopio no era solo de semejanza, sino de una aparente tangibilidad inmediata" (Crary 2008, 162), que añadía otro estímulo a la experiencia de observar fotografías. Para Von Helmholtz $(1962,303)$ y varios promotores del dispositivo, ${ }^{2}$ la experiencia real "no añadía nada a la apercepción obtenida con la estereoscopia al menos desde las relaciones de forma" (164) (citado en Crary 2008, 164). Su popularización aceleró la aparición de una crisis referencial (más allá de la relación entre realidad y simulacro), al manifestar la inhabilidad de los ojos para ver lo que se encuentra en el espacio (Silverman 2009), y desencadenó preguntas acerca de la percepción de la distancia y su relación con el cuerpo. Hoy en día, tanto en la realidad virtual como en la aumentada, la técnica otorga a los videojuegos y a diversos gadgets tecnológicos un nivel de propiocepción ideal para el control a distancia. Para mediados de siglo XIX y principios del siglo XX, la sensación de cercanía visual que otorgaba el dispositivo atañía a la cognición y se preguntaba por ella. Los libros de texto acompañados de estereofotografías en los Estados Unidos advertían a manera de prefacio las bondades de la enseñanza a partir de estereofotografías tanto como la necesidad de estudiarlas crítica e inquisitivamente frente a la información que se leía o escuchaba en clase (McMurry 1936).

Las ciencias experimentales del siglo XIX, de la mano de las propuestas artísticas de la época, acogían una experiencia visual activa y autónoma. El observar del hombre moderno era una experiencia que cuestionaba y analizaba activamente lo que el ojo veía. Para Crary (2008), la fisiología óptica de la que parte el estereoscopio pone a la visión como objeto del conocimiento; la respuesta del ojo a los fenómenos lumínicos y el movimiento está asociada a algunos procesos de cognición. La observación a través del estereoscopio obliga a hacer primero un paulatino movimiento de convergencia de la retina para que el ojo se adapte a la distancia a la que se encuentran las imágenes. Durante el tiempo de observación por medio del aparato, el ojo reacciona con pequeños movimientos denominados sacádicos, en los que el músculo ciliar se mueve constantemente para que la fóvea pueda acceder a puntos de enfoque específicos. Estos movimientos los hacemos todo el tiempo en nuestra experiencia visual cotidiana del espacio. Desde los puntos de convergencia se estimula una ilusión de profundidad, ${ }^{3}$ por ello inferimos que la visión estereoscópica poco tiene que ver con la representación del espacio, pues está más relacionada con la capacidad del cerebro por buscar convergencia. La imagen estereoscópica nos acerca a la "vertiginosa incertidumbre sobre las distancias que pudieran separar la formas, su exploración supone una acumulación o patchwork de diferentes intensidades de relieve sobre la misma imagen. Nuestros ojos siguen un sendero entrecortado y errático hacia su profundidad [acercándonos a los espacios de Bernhard Riemann analizados por Gilles Deleuze]" (166). La discontinuidad y la no convergencia son herramientas de reflexión sobre la realidad misma, discontinua, incongruente y nunca completa, sobre la cual buscamos relatos, historias, memorias e imágenes desde las que podamos extraer continuidades aparentes. El ojo recorre espacios no homogéneos y sigue los relieves de la imagen desde una experiencia háptica, en la cual se recorren las superficies en busca de puntos de convergencia que proponen una continuidad sensitiva. Cada recorrido por la imagen es diferente; distintos componentes de la imagen toman protagonismo en cada observación. 
Shattuck (1983) estudia la obra de Marcel Proust usando como metáfora diversos aparatos ópticos, para reflexionar sobre el tiempo, la visión y la percepción de la modernidad. Según Shattuck, la profundidad óptica del estereoscopio es para Proust la analogía perfecta para describir la percepción de la profundidad del tiempo. El principio de la estereoscopia en las metáforas temporales de Proust toma en consideración dos memorias suficientemente distantes la una de la otra que "but we have only to select in our memory two pictures taken of them at different moments, close enough together however for them no to have altered in themselves - perceptibly, that is to say- and the difference between the two pictures is a measure of the displacement that they have undergone in relation to us" (no causan el efecto de movimiento continuo, pero suficientemente emparentadas como para asociarse en un diseño formal reconocible) (151). La profundidad temporal es adquirida por dos experiencias cercanas en el tiempo que dan forma a la complejidad del relato en el recuerdo. Como artista, la visión de Proust responde a una solución estética y no a una visión aplicable a la vida. Sin embargo, Shattuck no invalida la expresión estética como método para apreciar una entidad en el tiempo. Los pequeños movimientos de convergencia de la memoria permiten desde la experiencia estética relacionar la vertiginosa incertidumbre de las distancias en la que se encuentran las memorias. Entendiendo la memoria desde el instante, desde ese momento específico cargado de complejidades, análogo al instante fotográfico y lo que este trae al afecto.

Tanto el ver como una actividad fisiológica específica como el observar como una actividad analítica son experiencias activas en las que el tiempo opera transformando la percepción. La estereoscopia se popularizó en los Estados Unidos junto con intereses expansionistas y un creciente sistema de imágenes del mundo, con lo cual posibilitó a un observador-consumidor de clase media acercarse a lugares que para la época no podrían ser visitados tan fácilmente. También le otorgó al estudiante estadounidenses el privilegio de conocer detalladamente las formas de vida y los acontecimientos alrededor del mundo.

Entre muchas de las fotografías estereoscópicas comercializadas, los tours estereoscópicos en particular fueron un producto que construyó relatos del mundo antes de la radio, el cine y la televisión. Estos sets de fotografías tomaban como tema un lugar capitalizable desde la imagen y lo exploraban a partir de fotografías, mapas y guías de viaje que seguían el recorrido por las imágenes añadiendo datos y observaciones del lugar. Las imágenes de los tours estereoscópicos también eran reagrupadas en colecciones mucho más extensas que promovían viajes alrededor del mundo a través del telebinocular (Holmes 1936), en el que se organizaban las imágenes por índices geográficos, agricultura, horticultura, etnias, culturas, arquitectura o historia, entre otras categorías, proponiendo diversas organizaciones de las mismas imágenes.

La idea de representación de un espacio distante y la sensación de tangibilidad de estas representaciones impulsó un mercado de destinos estereoscópicos que envió a muchos fotógrafos a desplazarse para retratar lugares lejanos, con el fin de traer dichos lugares ante los ojos del espectador. Al reverso de cada estereofotografía, comúnmente se encontraba impreso un trabajo en el que se precisaba el lugar fotografiado y se añadía información sobre este. El éxito mercantil de los tours estereoscópicos se apoya en la inmovilidad ligada a posiciones de poder tanto económico como racial o de género. ${ }^{4}$ El mercado del estereoscopio se ancló en la inmovilidad de muchos cuerpos y la posibilidad de transferir la experiencia tangible de dicha movilidad como conocimiento y poder. Los box sets, o cajas de 
colección, fueron en su época otro producto dirigido a familias con cierto poder adquisitivo, en el que se agrupaban secuencias organizadas de imágenes de diversos países del mundo. Estas cajas de colección fueron el primer producto que salió al mercado de las compañías Underwood \& Underwood y Keystone View Company en los Estados Unidos, antes que los libros de texto que incluían estereofotografías. América Latina fue fotografiada ampliamente al igual que muchos otros destinos del mundo. Las imágenes de Colombia corresponden a una serie de viajes realizados entre 1896 y 1940. El primer viaje registrado fue realizado por el fotógrafo estadounidense D. H. Ashton (Piedrahita 1987). ${ }^{5}$ Las estereofotografías correspondientes a este primer viaje recorren Barranquilla y sus alrededores aproximadamente ${ }^{6}$ para 1896, momento en el cual la ciudad era reconocida internacionalmente como el puerto marítimo del país. Más que un recorrido documental por Barranquilla, Ashton seguía pautas comerciales que aseguraban la publicación de las fotografías, manteniendo patrones utilizados incansablemente en tours de otros países, que reposaban en las salas de familias de clases privilegiadas en Norteamérica y Europa. Huhtamo (2006) desde la arqueología de los medios considera la estereoscopia como el primer medio masivo de corte social que se introduce en espacios privados. Para Huhtamo, este dispositivo se sitúa en la intimidad del hogar y genera relaciones de consumo y producción similares a los de la radio y la televisión (99). Las decisiones de producción de los tours estereoscópicos parten de intereses expansionistas propios de la modernidad y se integran a sistemas de producción serial que dan cuenta del gran sistema de producción asociado al dispositivo y su relación con nuestros ya muy conocidos sistemas de producción de consumo masivo como la televisión.

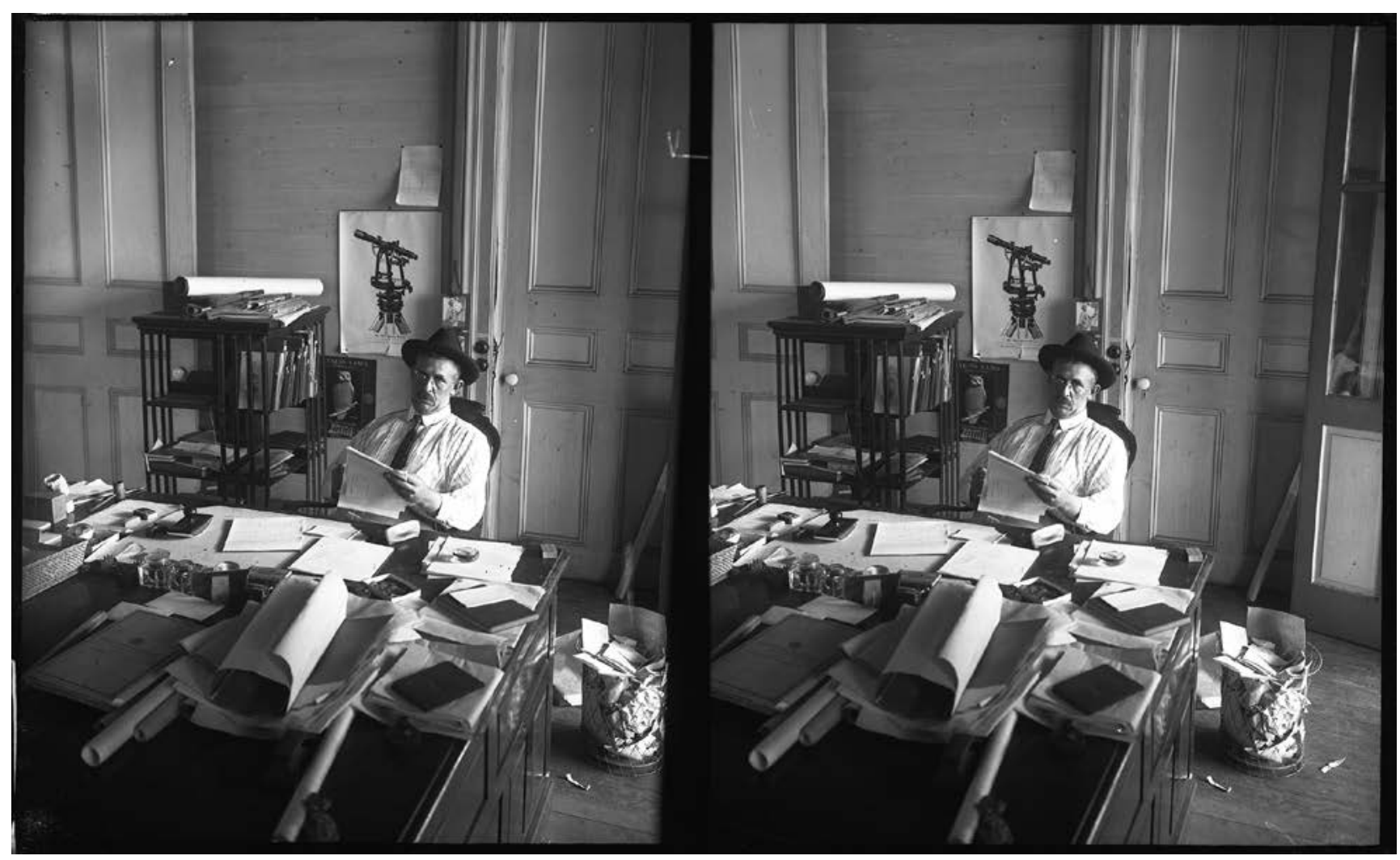

Figura 1. Man at desk, Panama. Keystone-Mast Collection, UCR/California Museum of Photography, University of California at Riverside. Impresión fotográfica 7,18 × 4,18 pulgadas. Registro 1996.0009.X89239. 


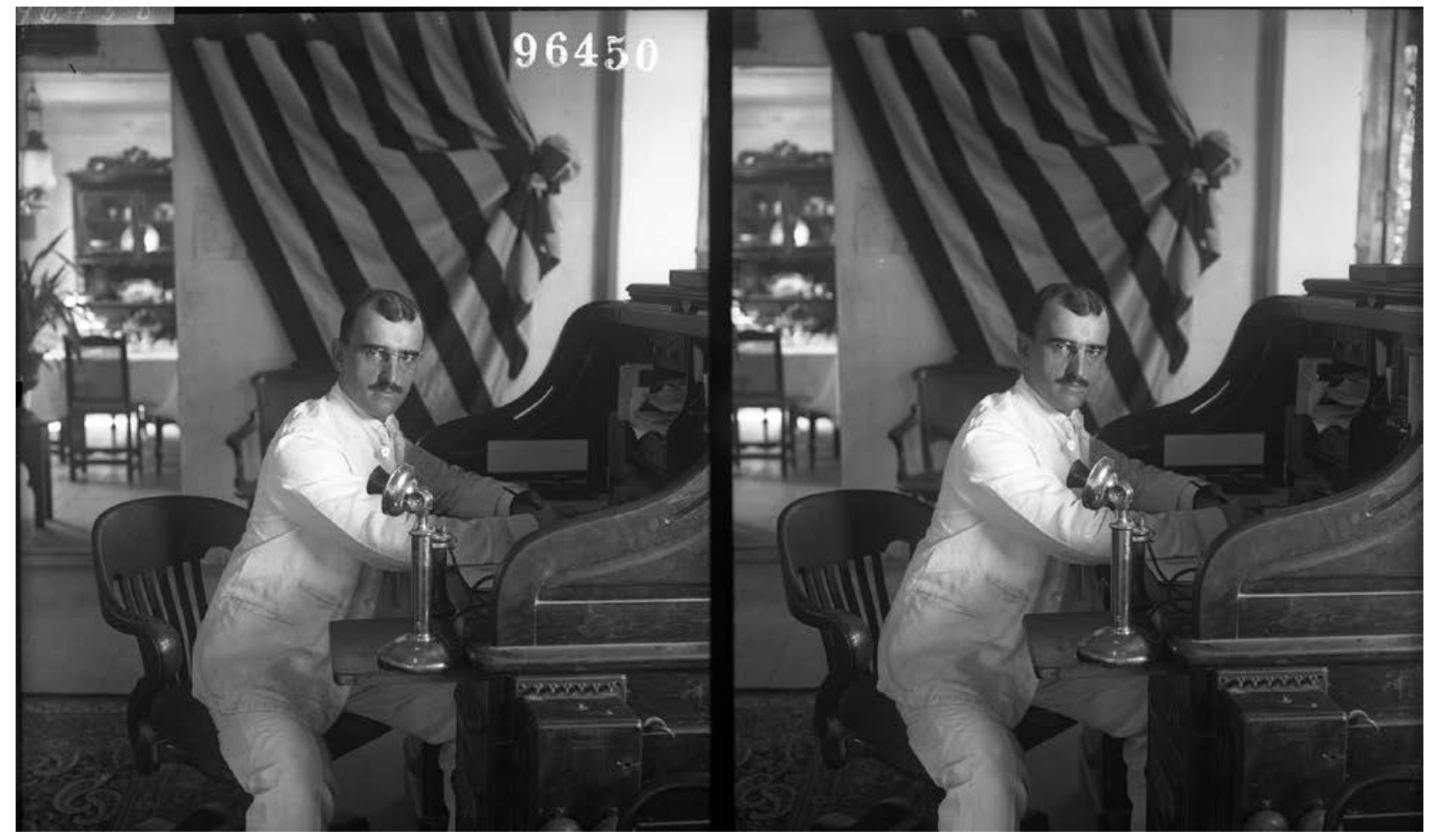

Figura 2. Man at his desk. Barranquilla, Columbia. Keystone-Mast Collection, UCR/California Museum of Photography, University of California at Riverside. Impresión fotográfica 7,18 × 4,18 pulgadas. Registro 1996.0009.X96450.

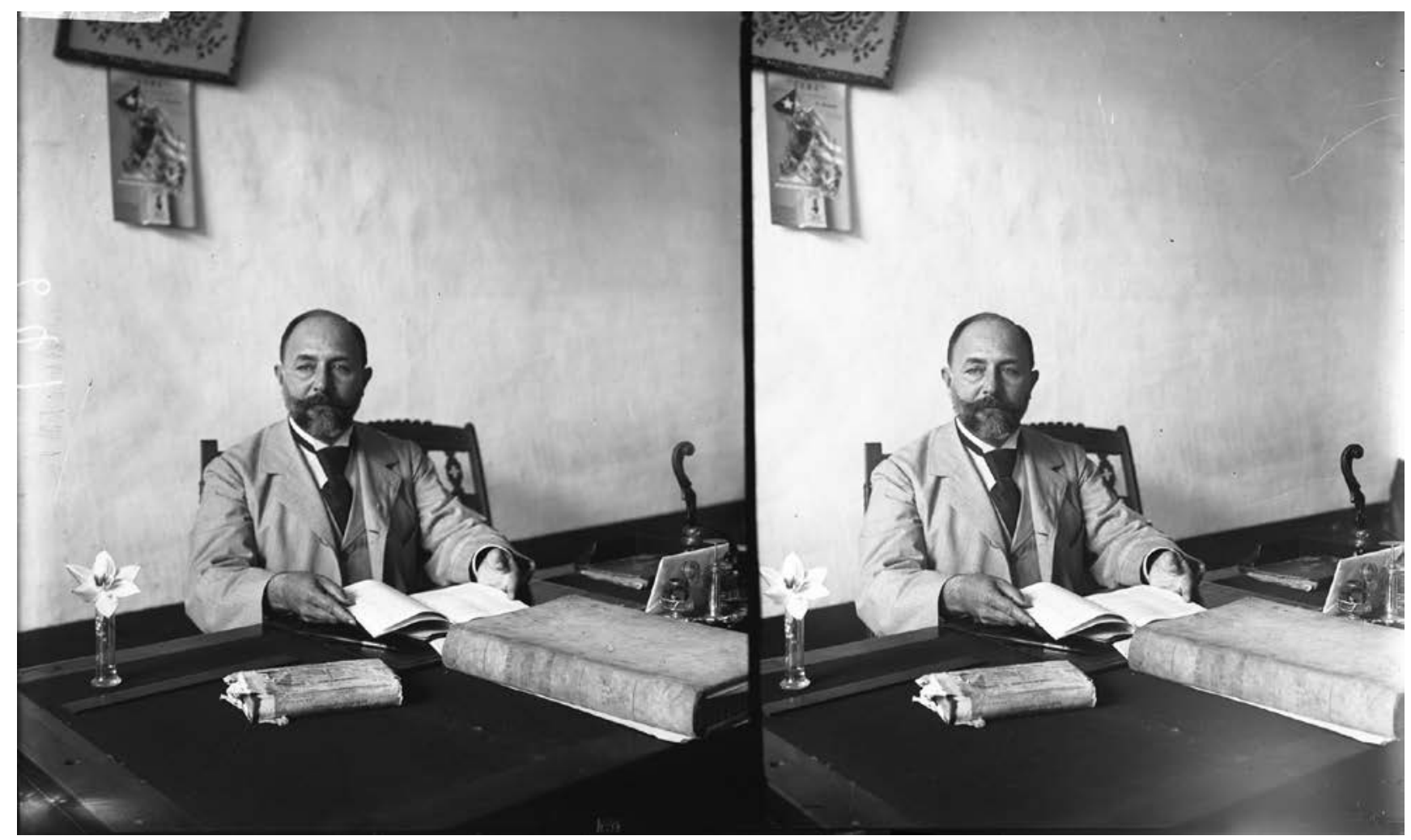

Figura 3. Man at his desk. Cuba. Keystone-Mast Collection, UCR/California Museum of Photography, University of California at Riverside. Impresión fotográfica 7,18 × 4,18 pulgadas. Registro 1996.0009.X46160. 


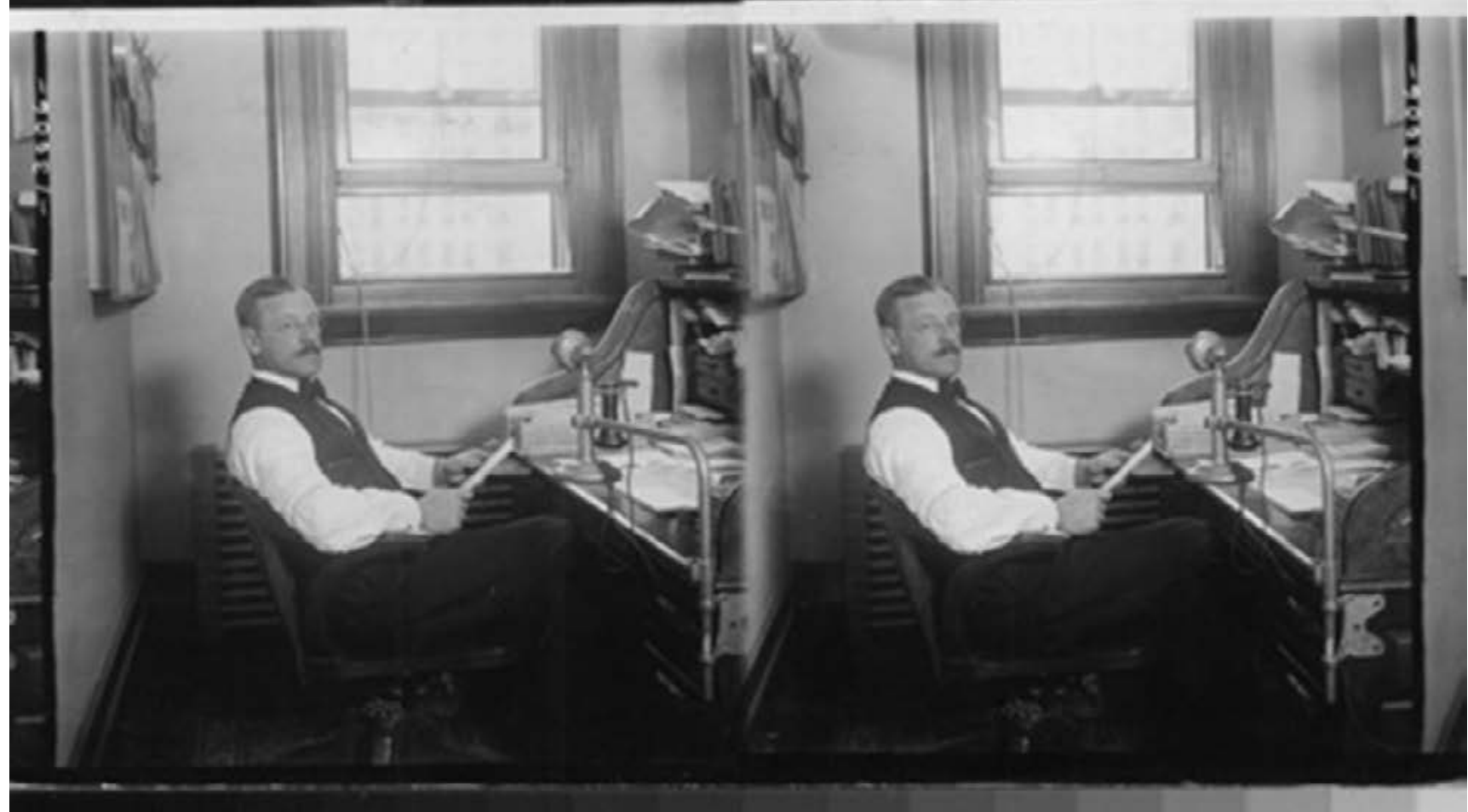

Figura 4. Mr. Jerome. District attorney at his desk. New York. Keystone-Mast Collection, UCR/California Museum of Photography, University of California at Riverside. Impresión fotográfica 7,18 × 4,18 pulgadas. Registro 1996.0009.WX13006.SS.

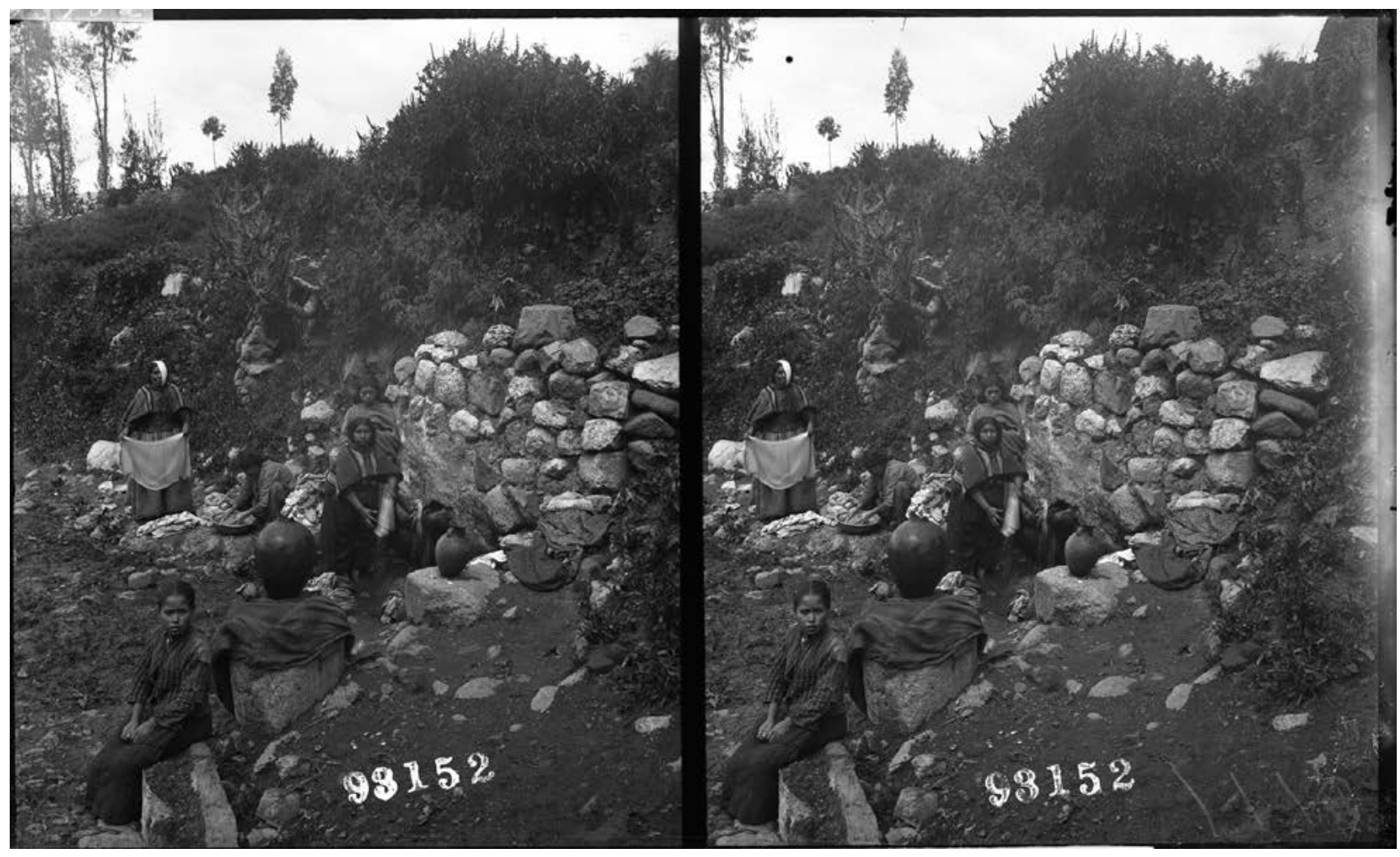

Figura 5. Wash Day. Cuzco. Perú. Keystone-Mast Collection, UCR/California Museum of Photography, University of California at Riverside. Impresión fotográfica 7,18 × 4,18 pulgadas. Registro 1996.0009.X93152. 


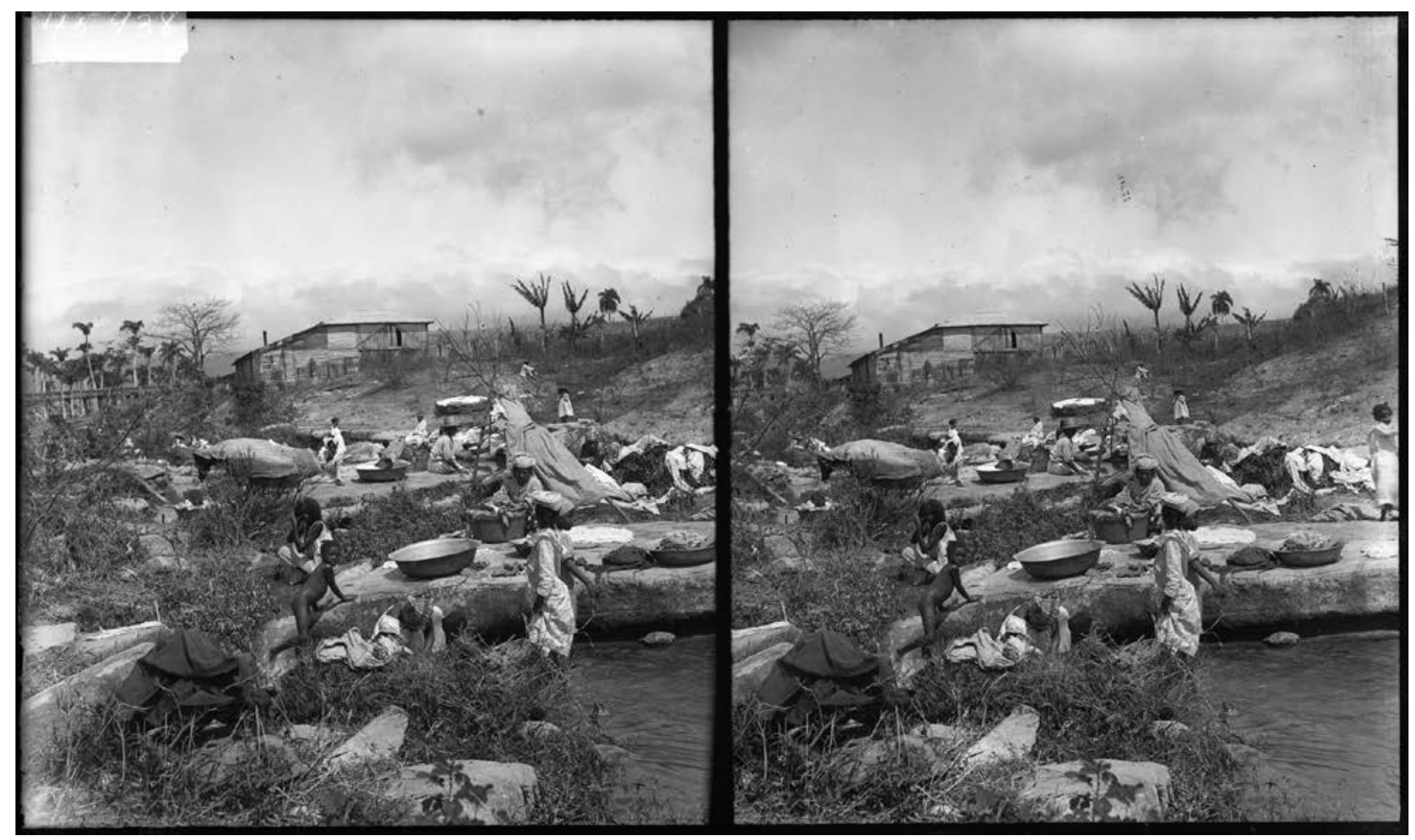

Figura 6. Wash Day. Cuba. Keystone-Mast Collection, UCR/California Museum of Photography, University of California at Riverside. Impresión fotográfica 7,18 × 4,18 pulgadas. Registro 1996.0009.X45938.

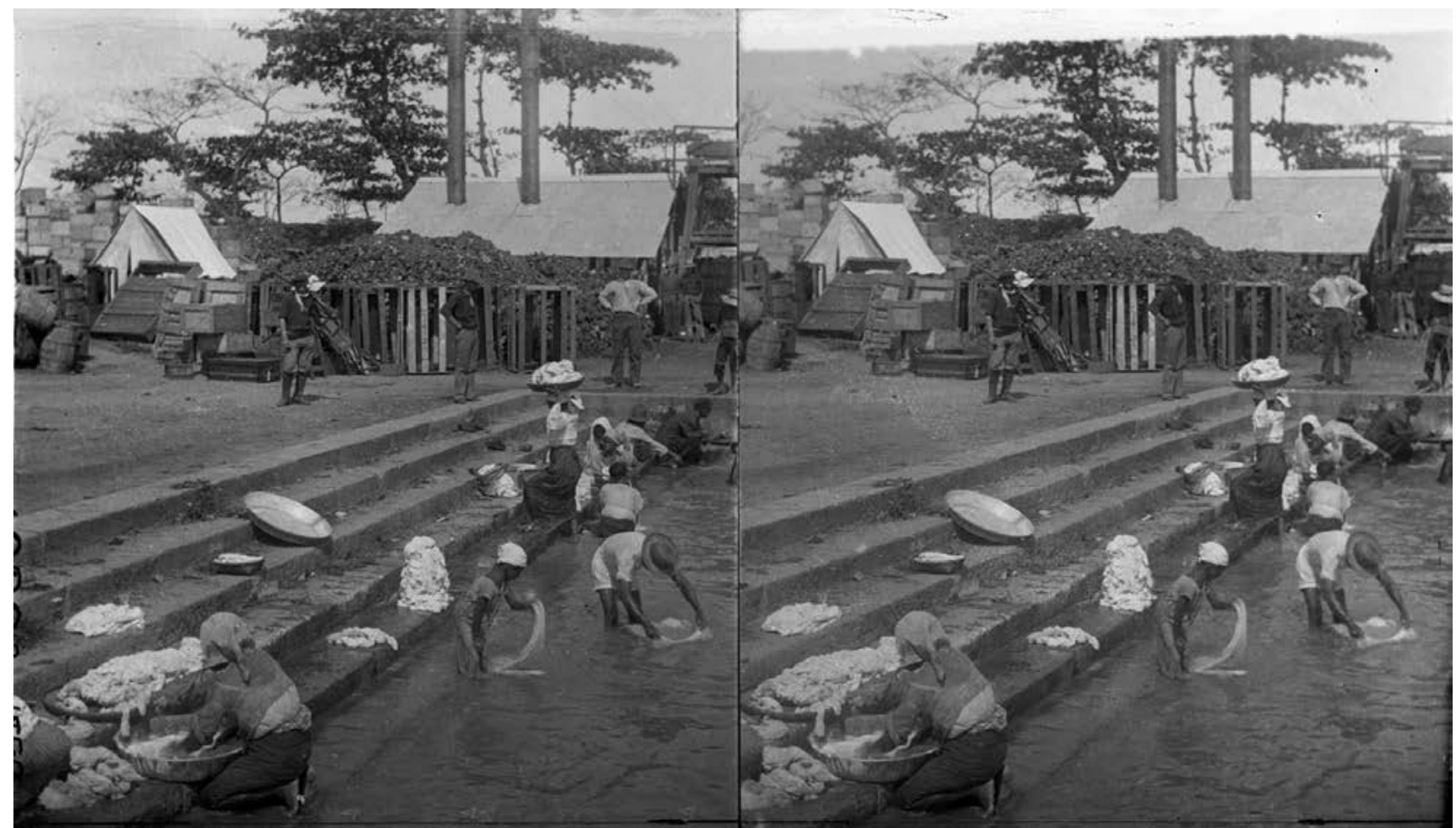

Figura 7. Filipino Wash - Day On The Banks Of The Pasig, Manila. Keystone-Mast Collection, UCR/California Museum of Photography, University of California at Riverside. Impresión fotográfica 7.18 × 4,18 pulgadas 
Lo títulos Men at desk (figuras 1, 2, 3 y 4) y Wash day (figuras 5, 6 y 7), por ejemplo, son categorías de estereofotografías recurrentes en viajes por diferentes países como Filipinas, Perú, Cuba o Panamá. Men at desk retrata el escenario de un hombre moderno de otro lugar del mundo frente a su escritorio, del cual no obtenemos nombre ni profesión. En las estereofotografías de hombres norteamericanos en su escritorio, por su parte, se detalla nombre completo y profesión. Estos sujetos sin nombre hacen parte de una categoría de hombre de negocios que permite al negociante norteamericano reconocer un escenario familiar en el país que visita desde la distancia. Otro caso particular es el de la categoría Washing day, en el que se retratan escenas costumbristas del lavado de ropa. Estas imágenes protagonizadas por mujeres y paisaje siguen composiciones provenientes, principalmente, de la pintura costumbrista, en las que la ropa limpia da cuenta de estándares sociales y actividades de una jornada laboral. El tema constituiría una investigación profunda en sí misma y excede los intereses del presente trabajo; sin embargo, es importante enumerar algunos de los temas que les competen a estas imágenes para entender un poco mejor el tipo de imágenes que se buscaban reproducir. En Perú, Cuba, Filipinas y Colombia, las escenas suceden al aire libre, realizadas por mujeres mayores en situaciones bastante precarias, mientras que en las estereofotografías norteamericanas la escena es infantil; en ella las niñas juegan a lavar ropa (figura 8). Ni en Men at desk ni en Washing day, se intenta desarrollar una visión crítica o comprometida con el lugar adonde se viaja. En ambos casos, las fotografías responden a categorías generales, sin embargo, son consideradas parte importante del acervo de la memoria visual del Caribe colombiano (González 2004), y su observación detallada en el presente permite construir otras narraciones que se conectan a procesos históricos de la ciudad.

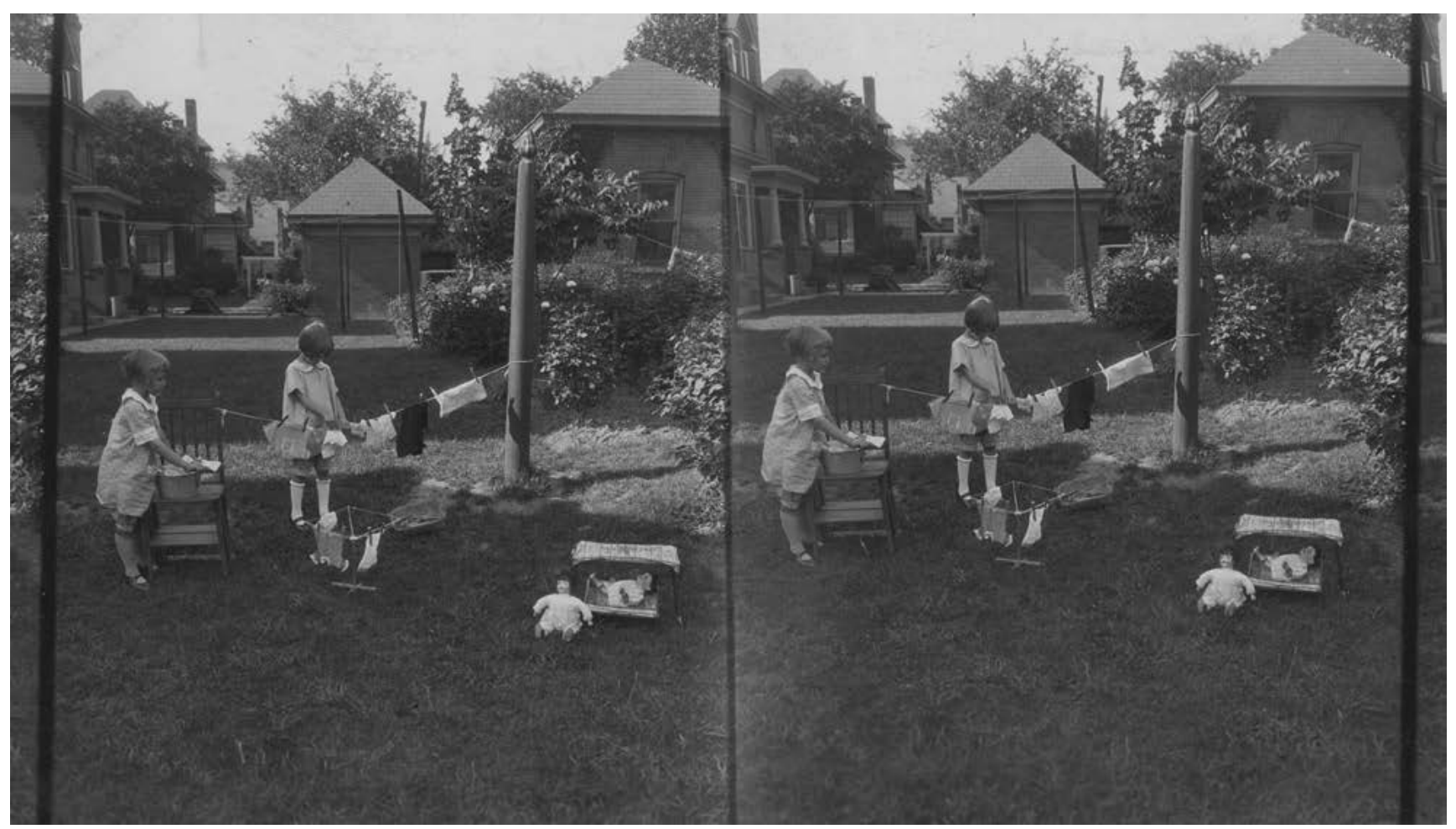

Figura 8. Wash Day. Pennsylvania. V. J. Stanton. Keystone-Mast Collection, UCR/California Museum of Photography, University of California at Riverside. Impresión fotográfica 7,18 × 4,18 pulgadas. 1927. Registro 1996.0009.21300. 
No existe en estas imágenes una exploración de Barranquilla más allá de una zona urbana reducida, no se registran las aguas de los caños que comunican a Barranquilla con otras zonas del Caribe, tampoco se abren preguntas sobre la gente fotografiada más allá de relaciones de poder básicas coloniales. La visión que nos presentan estos viajes a Barranquilla en el umbral del siglo XX es una visión mercantilizada, masificada, oscurecida por la generalizada geopolítica occidental y sumergida en los códigos visuales de un mercado colonial. Los box sets como productos de lujo siguieron lógicas del turismo mundial y dinámicas coloniales. Dentro de estas lógicas se tantean las características comerciables del lugar, se resaltan los exotismos reconocidos, se toman representaciones de memorias culturales producidas en otro lugar y se domestica el espacio dentro de un sistema "universal" de signos que el visitante cosmopolita reconoce y comunica (D'Hauteserre 2004; Urry 1990). Este reconocimiento puede aligerar el recorrido del visitante por el lugar, e incluso en muchos casos potencia el deseo por viajar. Para Urry (2002 [1990]), los turistas son como peregrinos tras los símbolos del lugar que visitan. Quienes viajan con un espíritu cosmopolita celebran y respetan las diferencias con la facilidad y el placer que otorga reconocer un lugar desde la apercepción.

Para Crank (2004), el turismo no es solo una actividad de consumo de lugares, sino que también es una fuerza que dinámicamente los crea. Crea mapas espacializando significados sociales; traza un relato sobre el territorio tomando mitos, sueños, ideas y acontecimientos. Al crear espacios y ubicarlos en un mapa, los integra a un relato local o global, que al igual que las carreteras diseña nuevas rutas y olvida otras. Los tours estereoscópicos señalan lugares y temas por observar. Observarlos hoy en día pone en la mira espacios que, aunque importantes a nivel comercial y esenciales patrimonialmente, han sido descuidados en su administración por nuevos proyectos cada vez más "modernos". Las estrategias administrativas de las ciudades hoy en día ven la memoria como un elemento opuesto al desarrollo económico. Actualmente, los centros históricos de las ciudades condensan capas complejas de urbanización, memorias, desplazamientos y un presente que responde continuamente a su aparentemente irremediable contexto. Por su parte, las dislocadas periferias siguen un cambio progresivo lejos del centro, obedeciendo a tendencias globales de consumo visibles en la arquitectura, la planificación urbana y las multinacionales. Durante diciembre de 2016 y enero de 2017, como parte del análisis a estas imágenes, realicé un recorrido por los espacios fotografiados por Ashton en el centro de Barranquilla. Al comienzo de mi visita, iba tras las huellas de edificaciones y personajes presentes en las imágenes. La información recolectada desde el archivo de la Universidad de California poco daba cuenta de las especificidades o ubicación de los espacios fotografiados. Llevar las estereofotografías a los ojos de historiadores barranquilleros y residentes del centro de la ciudad me permitió abrirme a otras rutas del Caribe que escapan a las imágenes exóticas de las campañas de reactivación turística nacional como Colombia es pasión, Vive Colombia viaja por ella o Colombia es realismo mágico, cuyas imágenes transitan alrededor de agendas comerciales en las que se vende exuberancia natural, paisajes remotos, artesanías de exportación o resorts frente al mar.

Llevar el espacio estereoscópico del viaje de Ashton a los ojos del transeúnte desprevenido tanto como del ciudadano especialista causó diversas reacciones de acuerdo con el lugar desde donde cada sujeto observaba. Comerciantes, trabajadores, habitantes y transeúntes del centro de la ciudad —Boliche, Paseo Bolívar, Plaza Ujueta, Plaza de San Nicolás e Intendencia Fluvial - reconocían las similitudes con los dispositivos de realidad virtual popularmente presumidos como novedosos. Reconocer los espacios que cotidianamente 
habitan en las estereofotografías que observaban durante mi visita resignificaba el entorno. El relato sobre Ashton, fotógrafo enviado por una empresa norteamericana para capturar imágenes del centro como tours de interés mundial, desligaba la relación del material de archivo de la colección de familias aburguesadas y lo traía al sistema de símbolos del turismo del que he venido hablando antes. Este pequeño giro adhiere, desde el turismo, un valor mercantil al espacio que detona memorias románticas de un pasado irrecuperable. La observación por medio del estereoscopio del material de archivo permitía recorrer los puntos de convergencia de la imagen habitando un pasado aparentemente cercano al presente. La reacción ante la novedad de la técnica era evidente en comparación con los ejercicios de reconocimiento de imágenes hechas sin el estereoscopio. Muchos de los comerciantes veían inmediatamente en el dispositivo y las estereofotografías el elemento potencial necesario para persuadir la mirada de la administración actual e impulsar la recuperación del centro histórico tal como se está haciendo en otras zonas de la ciudad, muchas otras ciudades del país y otras alrededor del mundo. Sin embargo, su promesa más grande parecía consistir en la visita del turista, en la reactivación del espacio a partir de la presencia de visitantes en algunos casos extranjeros y en otros de barranquilleros habitantes de periferias que no sienten necesidad de ir al centro y tampoco se identifican con él.

Por su parte, el historiador barranquillero, desde su mirada especialista, reconocía muchas de las imágenes como herramientas de trabajo. La visión del historiador inquisitivamente exploraba los espacios de la imagen y revisaba información ya adquirida desde una posición de conocedor de la historia. Con precisión, estos observadores ubicaban los lugares fotografiados y daban cuenta de los cambios evidentes tras un siglo. Su relato se entremezclaba entre datos traídos de libros, fotografías, experiencias familiares y conjeturas. En la iglesia de San Nicolás, por ejemplo, el historiador Adlai Stevenson asegura que la fotografía fue tomada alrededor de 1896 y no en 1913 fecha registrada por anteriores investigaciones. Para Stevenson, la estructura disímil de las torres de la iglesia fue anterior a su remodelación en 1897 por Amadeo Mastellari, según su propia investigación y fuentes. Tanto el historiador como el ciudadano del centro, una vez exploraban las imágenes por uno o tres minutos, retiraban el dispositivo de sus ojos y relataban sus memorias, hallazgos o comentarios. La experiencia con el dispositivo en la mayoría de los casos resultaba en una pequeña anécdota que resonaba en los afectos del observador. Las imágenes detonaban reflexiones sobre la vida en la Barranquilla de principios del siglo XX, las malas decisiones administrativas, los oficios informales, la fundación de la ciudad, el comercio local y el desplazamiento de los mokanás -nativos de la región - de los centros urbanos, entre muchos otros temas que aparecían tangencialmente en las estereofotografías. En las exploraciones de los ciudadanos ya no hay cabida para las categorías y las clasificaciones; su recorrido visual es desprevenido paseando por las superficies de la imagen y la memoria.

Para Huhtamo (2006), a diferencia de otros investigadores, observar por medio del estereoscopio estaba lejos de ser una experiencia individual; las imágenes de archivo recuperadas por el investigador daban cuenta de reuniones en las que el estereoscopio hacía parte de las actividades grupales en salas de visita. Durante el trabajo de campo en Barranquilla, a partir de la interacción de por lo menos unas cuarenta personas con el material, pude observar que la sensación tridimensional estimulaba la necesidad de comunicar la experiencia. Una vez observado, la persona invitaba a otros a observar, indicando la manera en que debía tomar el aparato y concentrarse en la imagen que comienza a tomar nitidez en el centro 
del campo visual. Las imágenes que en algún momento fueron un producto comercializable y generalizador frente al mercado de destinos estereoscópicos, con estas actividades, se transformaron en detonantes de memorias compartidas en colectivo. El turismo visual del siglo XX en este caso recupera un relato que para muchos estaba en el olvido como la historia misma. Este olvido parece ser una característica del habitar por el espacio y pasar desapercibidas las edificaciones de escenarios cotidianos. La sensación espacial del estereoscopio y la ruta determinada por las fotografías del norteamericano activaron desde el cuerpo -específicamente desde sus movimientos sacádicos- rutas a la memoria individual y la historia del centro de la ciudad. Los ciudadanos más jóvenes referían a otros mayores para observar junto a ellos. Por su parte, los mayores trataban de precisar la ubicación de los lugares fotografiados y en su intento navegaban por relatos de su infancia, los cuales cruzaban el caño del mercado, el puente Ferrans, el antiguo mercado de granos y la calle de las vacas, entre muchos lugares y eventos que resuenan en la memoria colectiva, como el incendio ocurrido en la plaza de San Nicolás, establecimientos comerciales conocidos por el nombre de sus dueños o la existencia de placas para coches de mulas.

En las estereofotografías y la actividad realizada con los habitantes del centro histórico de Barranquilla, tanto jóvenes como ciudadanos mayores de 75 años podían relacionarse de una manera directa con el espacio fotografiado. En los más jóvenes, en diversos casos, era importante compartir referencias de la investigación previa y charlas con otros barranquilleros. Para los ciudadanos mayores, el encuentro con la imagen era casi instantáneo, incluso la exploración de la estereofotografía Men at desk y Washing day, de las que hablé anteriormente, concurría referencias inmediatas. En la primera, el personaje de la fotografía era relacionado con Elías Pellet, personaje pionero de la radio comercial en Colombia. Y aunque su imagen no concuerda con las fotos de archivo de Pellet y el personaje en la estereofotografía, probablemente fue un inmigrante norteamericano de la burguesía; los relatos sobre la radio eran detonados, junto con señalamientos al progresismo barranquillero. En Washing day (figuras 9 y 10), se referenciaba inmediatamente a las lavanderas y los aguateros, dos de los oficios más comunes de la ciudad. Las lavanderas lavaban ropa por encargo en las zonas de los caños con menor profundidad y los aguateros se encargaban de llevar el agua por toda la zona urbana, lo cual denota también recuerdos de los oficios y las actividades cotidianas de sus padres e infancias. Otras dos fotografías encontradas en el archivo, de las que no se sabe si fueron publicadas, hacen referencia también al día de lavado. En una de ellas (figura 11), una mujer está sentada delante de una cuerda para secar ropa, acompañada por un par de chicos más jóvenes que parecen descansar bajo la sombra. En diferentes imágenes como la descrita, bajo techos de palma, son identificados los descendientes de mokanás, una etnia del Atlántico que comerciaba pescado y víveres además de lavar ropa en los alrededores de Barranquilla. De lo poco que queda de la cultura es su patrimonio culinario y un petroglifo por la región del Morro reconocido como piedra pintada. 


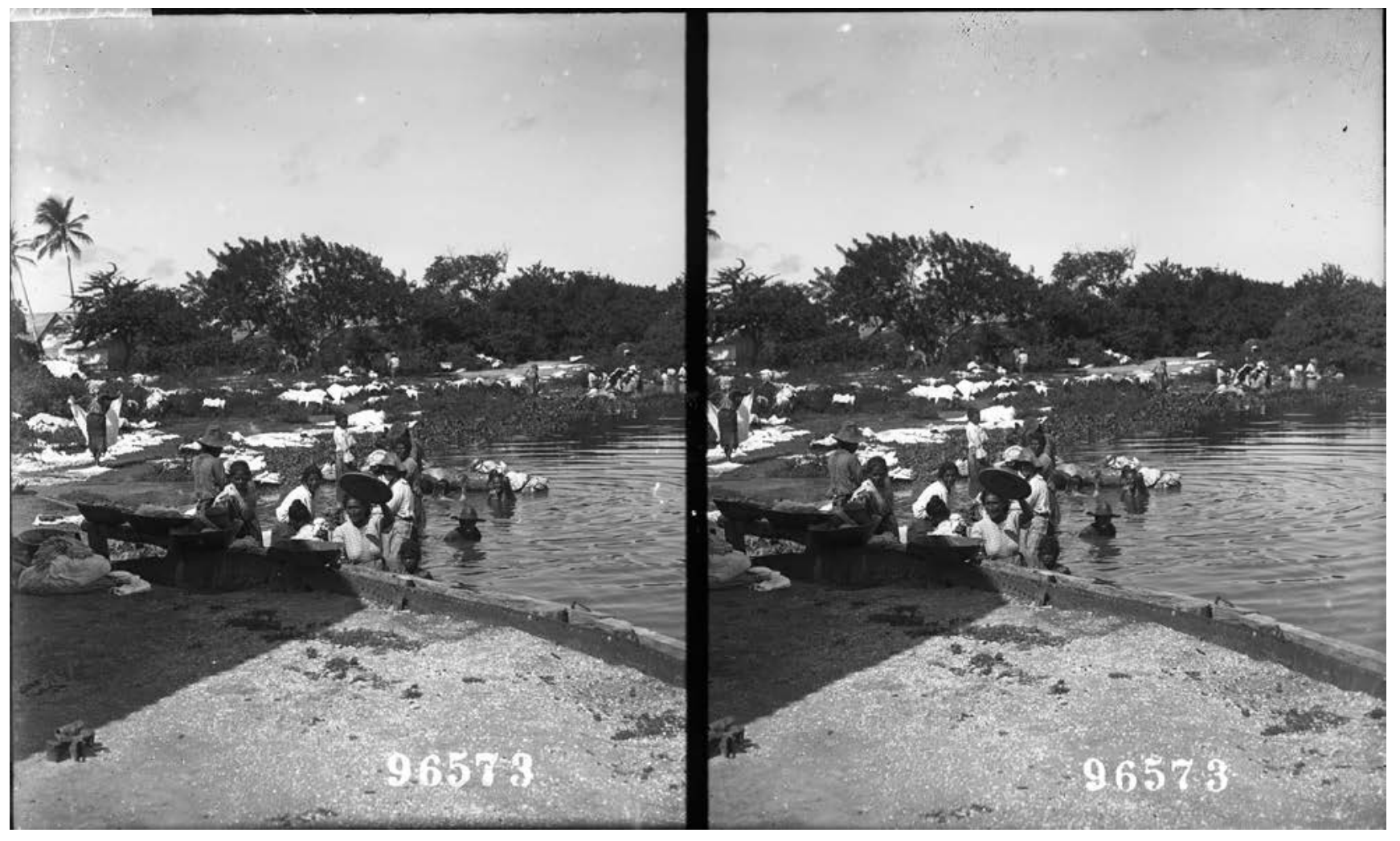

Figura 9. A Colombian Washing Day - Along the Magdalena River Near Barranquilla, Columbia. S.A. Keystone-Mast Collection, UCR/California Museum of Photography, University of California at Riverside. Impresión fotográfica 7,18 × 4,18 pulgadas. Registro 1996.0009.X11517.

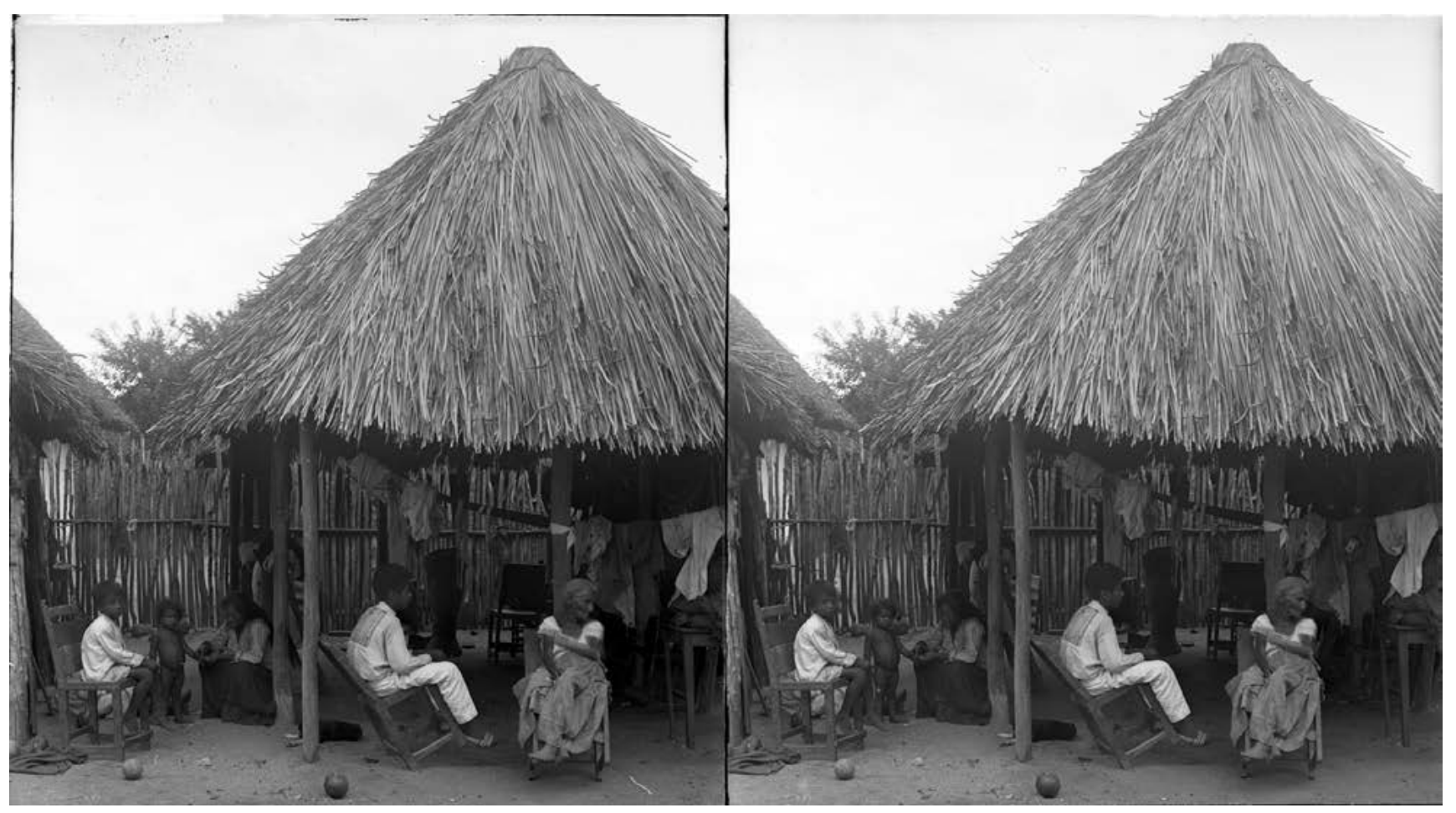

Figura 10. A typical thatched roofed home in picturesque Barranquilla, Columbia. S.A Keystone-Mast Collection, UCR/California Museum of Photography, University of California at Riverside. Impresión fotográfica 7,18 × 4,18 pulgadas. Registro 1996.0009.X11516. 


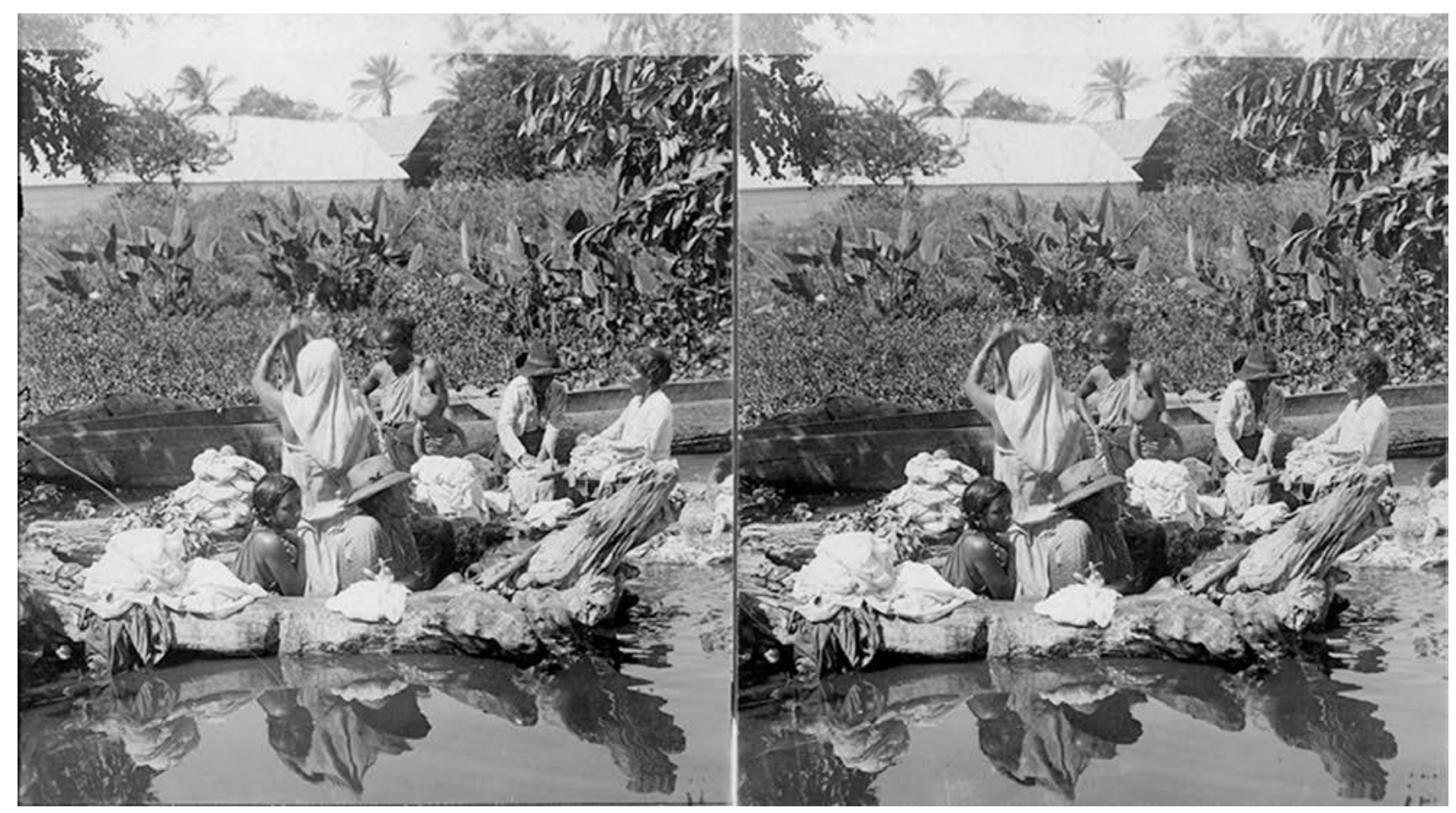

Figura 11. A Colombian Washing Day - Along the Magdalena River Near Barranquilla, Columbia. S.A. Keystone-Mast Collection, UCR/California Museum of Photography, University of California at Riverside. Impresión fotográfica 7,18 × 4,18 pulgadas. Registro 1996.0009.X96573.

Para la era victoriana, la característica de tangibilidad de la estereoscopia provee un tipo de saber tan confiable como el conocimiento proveniente del tacto, que acerca los objetos al cuerpo y los conecta con su espacio fronterizo. Sin embargo, el estereoscopio no está claramente relacionado con el tacto, sino que este manifiesta la relación entre lo visual y lo táctil, pero se enmarca en estructuras perspectivistas como la profundidad de campo y el perspectivismo escenográfico del teatro. Para Merleau-Ponty (1968), el entendimiento del espacio proviene del movimiento y las fuerzas que nuestro cuerpo ejerce sobre el mundo no de proyecciones geométricas perspectivistas, entendiendo que ese cuerpo está conformado por diversas complejidades además de un par de ojos. Por lo que mantener la consciencia de esta aparente conexión y de la facultad del cuerpo por buscar puntos convergentes y no convergentes es un punto interesante de despliegue frente a las nuevas propuestas tecnológicas que le atañen a la técnica.

Hoy en día, el resurgimiento de la estereoscopia con Google Glass, Google Cardboard y Oculus Rift, entre otros, explora nuevos campos del entretenimiento, adicional a la industria cinematográfica del 3D y los videojuegos. El capital invertido en este tipo de tecnologías es significativo al igual que el invertido en tecnologías digitales y amplias zonas de conexión a internet en el mundo. Siguiendo ese panorama, parece importante hacer revisiones detalladas a sus potenciales usos, de manera que no se sepulten en la abundancia de experiencias inmersivas fugaces, enlazadas a productos promocionales a favor de un turismo de apariencias o de videojuegos que solo se concentran en desarrollar competitividades. La cadena de hoteles Marriot fundada desde 1950 ha estado lanzando desde 2014 dispositivos en sus hoteles en los que promociona sus paquetes turísticos desde la inmersión estereoscópica. En 2014, lanzó una serie de estaciones VR 4D denominadas Teleporter, en la que los 
huéspedes pueden tener una experiencia inmersiva visitando diversos destinos turísticos donde se puede acceder a los servicios de la cadena. Las cabinas Teleporter adicionalmente tienen motores, sensores de movimiento y generadores de calor, viento y olores para crear una experiencia inmersiva más compleja. Para 2015, la cadena lanzó una maleta discreta, la cual es ofrecida a los huéspedes con el fin de reproducir videos elaborados por la cadena promocionando destinos turísticos como material estereoscópico disponible en YouTube o videojuegos. Esta iniciativa hace parte de una estrategia que busca entrar en el mercado de los denominados millennials con expectativas de expansión del mercado turístico en los próximos años.

En sus principios, la inmersión producida por la estereoscopia fue valiosa por su despliegue de imágenes que revelan relaciones complejas entre la visión, el espacio y la cognición. Keystone View Company encontró un mercado interesante en la educación que naturalmente fue desapareciendo con el marketing de otras ayudas educativas que hacían uso del cine. Hoy en día, podríamos decir que, al relacionar el dispositivo con otras temporalidades, expandimos las complejas relaciones entre lugar, visión, inmersión y tiempo. Al ser consciente de estas facultades de la técnica, es posible transcender sus afecciones básicas, sumando cartografías interesantes a muestro espacio sensitivo. Tener consciencia de la separación encubierta con la que nos acercamos a las imágenes a través del dispositivo genera discursos que cuestionan o, por lo menos, problematizan el distanciamiento. Como en La cueva de los sueños olvidados del cineasta alemán Werner Herzog (2010), documental que explora desde el 3D las imágenes inscritas hace más de 30000 años en las cuevas de Chauvet al sur de Francia. ${ }^{9}$ Este, hoy en día, es la manera de simular la experiencia de un espacio al cual no es posible acceder por motivos de conservación. Existen diversas aplicaciones donde la observación de propuestas artísticas podría problematizar espacios históricos, microscópicos o telescópicos, a la vez que muchas aplicaciones sucesoras de la tecnología como la aerofotografía estereoscópica y los simuladores de vuelo militar modernos. En suma, este escueto análisis busca señalar la posibilidad de relacionarse con la técnica, diferente de aquellas que solo buscan una inmersión para acercarse a espacios idílicos. Como aquellos ofrecidos por Marriott International estratégicamente diseñados para acercarse a un lugar sin ser tocados por los cuerpos que lo habitan cotidianamente. $Y$ cuestionar nuestras amañadas distancias a lo que observamos. 


\section{NOTAS}

1 Para Comolli (2010), ojo y cámara son entes relacionados no equivalentes, pues, desde una posición historicista, la multiplicidad de instrumentos ópticos ha dispuesto miles de visiones tras la mirada de hoy. Asimismo, el ojo no se encuentra frente a una cámara, sino frente a un dispositivo de producción de imágenes que desplaza y a la vez legitima la visión humana. Los cientos de pequeñas máquinas del siglo XIX destinadas a la reproducción de la imagen hacen parte de la taxonomía de una gran máquina de representación de la cual las sociedades han participado (122). La cámara confirma las leyes de la perspectiva que le han dado a la visión monocular lugar primordial en la visualidad y, a su vez, desplaza la visión humana al señalar sus falencias (124).

2 Personajes como Burton Holmes, cineasta y promotor de las conferencias documentadas de viaje Documentary Travel Lectures, y Charles William Eliot, ilustre académico, profesor del MIT, presidente de la Universidad de Harvard en 1869 y promotor de la investigación cientificista en la academia, fueron algunos de los tantos promotores del estereoscopio, cuyos escritos alrededor propagandistas eran publicados en cuadernillos de las mismas empresas fabricantes como A Trip Around the World Through the Telebinocular de Keystone View Company.

3 "But the stereoscopic creation is due solely to the superposition of the two planes pictures by the optical apparatus employed, and to the distinct and instantaneous perception of distance by the convergency of the optic axes upon the similar points of the two pictures which the stereoscope has united" (El relieve no se obtiene de la simple combinación o superposición de dos imágenes dispares. La superposición se efectúa dirigiendo el ojo hacia el objeto, pero el relieve es proporcionado por el juego de los ejes del ojo que van alternándose sucesivamente de acuerdo con $-\mathrm{y}$ unificando- los puntos semejantes de cada imagen) (Brewster 1856).

4 Charles Dickens en 1850 relata la historia de Mr. Booley: "It is only in his eye that the adventurous character of Mr. Booley is seen to shine. It is moist, bright eye, of a cheerful expression, indicative of keen and eager curiosity" (Un prestigioso londinense de 65 años, corpulento y de baja estatura, cuyo ojo, describe Dickens, como aventurero, húmedo brillante, con una expresión alegre, e indicativa de una curiosidad entusiasta y ansiosa) (p. 73; traducción propia). El personaje de Dickens solo se aventuró a viajar luego de sus 65 años, con tanta suerte que nunca se vistió diferente ni dejó de lado sus costumbres o vestido inglés, ni tampoco se preocupó por hablar otra cosa que su lengua materna. Este personaje, miembro del Club de las Ostras (p. 73), es un espectador que señala en la época la capitalización de las experiencias estandarizadas y su próspera comercialización. Mr. Booley logró a sus 65 años conocer lugares del mundo que jamás hubiese sido posible sin ayuda de los panoramas móviles emplazados en espacio público, los peep shows o el estereoscopio.

5 Los negativos en placas de vidrio hacen parte de la colección del UCR/California Museum of Photography en Riverside (California).

6 Las fechas consignadas en las investigaciones de Hilda Piedrahita no coinciden con fechas históricas reconocidas por historiadores barranquilleros como Adlai Stevenson, quien, en una entrevista con la autora del texto, acerca las fotografías a 1896, dadas las características arquitectónicas de la iglesia de San Nicolás en las estereofotografías de la colección de la Universidad de California.

7 Nótese en esta serie de fotografías cómo los hombres que posan frente a la cámara no son enunciados por su nombre, excepto en el caso del hombre que posa frente a su escritorio de quien conocemos su nombre con mucha familiaridad: Mr. Jerome.

8 En esta serie de fotografías, toman el lavado de la ropa como un tema costumbrista, en el cual se observan personas de diferentes países que lavan su ropa cerca de un río. En el caso estadounidense, consiste en una escena en la que se encuentran dos niñas que juegan al lavado de ropa en el patio de su casa.

9 La cueva de Chauvet es el lugar del más reciente descubrimiento arqueológico de pinturas rupestres, posiblemente anterior al Paleolítico Superior, en el cual se representan animales prehistóricos nunca antes vistos. La cueva está denominada patrimonio de la humanidad y por motivos de conservación se mantiene cerrada al público. 


\section{REFERENCIAS}

Brewster, David. 1856. The Stereoscope; Its History, Theory and Construction, with Its Application to the Fine and Useful Arts and to Education. Londres: John Murray. Consultado febrero 19, 2017. https:// bit.ly/2IBg9Xo

Comolli, Jean-Louis. 1980. "Machines of the Visible". En The Cinematic Apparatus, editado por Teresa de Lauretis y Stephen Heath, 121-142. Basingstoke, UK: Macmillan Press.

- 2010. Cine contra espectáculo seguido de técnica e ideología: 1971-1972. Buenos Aires: Manantial.

Crank, Mike. 2004. "Cultural Geographies of Tourism". En A Companion to Tourism, editado por Alan A. Lew, C. Michael Hall y Allan M. Williams, 74-84. Blackwell Publishing: Oxford.

Crary, Jonathan. 2008. Las técnicas del observador: visión y modernidad en el siglo XIX. Murcia: Cendeac.

González Cueto, Danny. 2004. "Una memoria visual para el futuro: la situación de los archivos fotográficos en el Caribe Colombiano." Memorias: Revista Digital de Historia y Arqueología desde el Caribe 1 (1). Consultado mayo 2, 2017. https://bit.ly/2Ktse2r

Dickens, C. (1850). "Some Account of an Extraordinary Traveller". Household Words, 1(4), 73-77.

D'Hauteserre, Anne-Marie. 2004. "Postcolonialism, Colonialism, and Tourism. En A Companion to Tourism", editado por Alan A. Lew, C. Michael Hall y Allan M. Williams, 235-245. Publishing: Oxford.

Helmholtz, Hermann von. 1962. Handbook of Physiological Optics. Vol. 3. Traducido por Georuge T. Ladd. Nueva York: Dover.

Herzog, Werner. 2010. La cueva de los sueños olvidados. Arte France.

Huhtamo, Erkki. 2006. "The Pleasures of the Peephole: An Archaeological Exploration of Peep Media". En Book of Imaginary Media: Excavating the Dream of the Ultimate Communication Medium, editado por Eric Kluitenberg, 74-155. Ámsterdam: NAi Publishers.

Holmes, Burton. 1936. A Trip Around the World Through the Telebinocular in Three Dimension Pictures. Pennsylvania: Keystone View Company.

Piedrahita, Hilda. 1987. Estereofotografías norteamericanas: una mirada sobre América Latina en tres dimensiones. Catálogo de exposición. Bogotá: Fondo Cultural Cafetero.

McMurry, Frank M. 1936. A Trip Around the World Through the Telebinocular in Three Dimension Pictures. Editado por Burton Holmes. Pennsylvania: Keystone View Company.

Merleau-Ponty, M. (1968). "The Intertwining: The Chiasm". The Visible and the Invisible 146: 511-520.

Shattuck, Roger. 1983. Proust's Binoculars: A Study of Memory, Time, and Recognition in A la recherche du temps perdu. Princeton Press: New Jersey.

Silverman, Kaja. 2009. El umbral del mundo visible. Traducido por Alfredo Brotons Muñoz. Madrid: Akal.

Urry, John. 2002 [1990]. The Tourist Gaze: Leisure an Travel in Contemporary Societies. Londres: Sage.

\section{MATERIAL VISUAL}

Man at desk, Panama. Keystone-Mast Collection, UCR/California Museum of Photography, University of California at Riverside. Impresión fotográfica 7,18 × 4,18 pulgadas. Registro 1996.0009.X89239. http://oac.collib.org/ark:/13030/kt2r29p5n8/?order=2\&brand=oac4

Man at his desk. Barranquilla, Columbia. Keystone-Mast Collection, UCR/California Museum of Photography, University of California at Riverside. Impresión fotográfica 7,18 × 4,18 pulgadas. Registro 1996.0009.X96450. http://oac.cdlib.org/ark:/13030/kt1m3nb89w/?order=2\&brand=oac4

Man at his desk. Cuba. Keystone-Mast Collection, UCR/California Museum of Photography, University of California at Riverside. Impresión fotográfica $7.18 \times 4,18$ pulgadas. Registro 1996.0009.X46160. http://oac.collib.org/ark:/13030/kt8000158v/?brand=oac4

Mr. Jerome. District attorney at his desk. New York. Keystone-Mast Collection, UCR/California Museum 
of Photography, University of California at Riverside. Impresión fotográfica $7.18 \times 4,18$ pulgadas. Registro 1996.0009.WX13006.SS. http://oac.cdlib.org/ark:/13030/kt1 g5014t6/?order=2\&brand=oac4

Wash Day. Cuzco. Perú. Keystone-Mast Collection, UCR/California Museum of Photography, University of California at Riverside. Impresión fotográfica $7.18 \times 4,18$ pulgadas. Registro 1996.0009.X93152. http://content.cdlib.org/ark:/13030/kt4580146v/?order=2\&brand=calisphere

Wash Day. Cuba. Keystone-Mast Collection, UCR/California Museum of Photography, University of California at Riverside. Impresión fotográfica $7.18 \times 4,18$ pulgadas. Registro 1996.0009.X45938. http://oac.cdlib.org/ark:/13030/kt3f59p5vq/?order=2\&brand=oac4

Filipino Wash - Day OnThe Banks OfThe Pasig, Manila. Keystone-Mast Collection, UCR/California Museum of Photography, University of California at Riverside. Impresión fotográfica $7.18 \times 4,18$ pulgadas. Registro 1996.0009.V10003. http://oac.cdlib.org/ark:/13030/kt829015nn/?order=2\&brand=oac4

Wash Day. Pennsylvania. V. J. Stanton. Keystone-Mast Collection, UCR/California Museum of Photography, University of California at Riverside. Impresión fotográfica $7.18 \times 4,18$ pulgadas. 1927. Registro 1996.0009.21300. http://oac.cdlib.org/ark:/13030/kt9b69q2vx/?order=2\&brand=oac4

A Colombian Washing Day - Along the Magdalena River Near Barranquilla, Columbia. S.A. Keystone-Mast Collection, UCR/California Museum of Photography, University of California at Riverside. Impresión fotográfica 7,18 × 4,18 pulgadas. Registro 1996.0009.X11517. http://oac.cdlib.org/ark:/13030/ kt4k4012s9/?order=2\&brand=oac4

A Colombian Washing Day - Along the Magdalena River Near Barranquilla, Columbia. S.A. Keystone-Mast Collection, UCR/California Museum of Photography, University of California at Riverside. Impresión fotográfica 7,18 × 4,18 pulgadas. Registro 1996.0009.X96573. http://oac.cdlib.org/ark:/13030/ kt3k40129r/?order $=2 \&$ brand=oac4

A typical thatched roofed home in picturesque Barranquilla, Columbia. S.A Keystone-Mast Collection, UCR/ California Museum of Photography, University of California at Riverside. Impresión fotográfica 7,18 × 4,18 pulgadas. Registro 1996.0009.X11516 http://oac.cdlib.org/ark:/13030/kt000009z6/?brand=oac4

\section{Cómo citar:}

Piedrahita, Angélica. 2018. “Inmersión y estereoscopia por la Barranquilla de comienzos del siglo XX". Cuadernos de Música, Artes Visuales y Artes Escénicas 13 (2): 27-45.

http://doi.org/10.11144/javeriana.mavae13-2.iyep 